\title{
THE EFFECTS OF AGRICULTURAL ACTIVITIES AND ATMOSPHERIC ACID DEPOSITION ON CARBONATE WEATHERING IN A SMALL KARSTIC AGRICULTURAL CATCHMENT, SOUTHWEST CHINA
}

\section{VPLIV KMETIJSKE DEJAVNOSTI IN KISLIH USEDLIN IZ ZRAKA NA PREPEREVANJE KARBONATOV NA MAJHNEM KRAŠKEM KMETIJSKEM OBMOČJU NA JUGOZAHODU KITAJSKE}

\author{
Yu CHEN $^{1} \&$ Yongjun JIANG ${ }^{1,2^{*}}$
}

\begin{abstract}
UDC 552.54:551.3.053(513)

Yu Chen \& Yongjun Jiang: The effects of agricultural activities and atmospheric acid deposition on carbonate weathering in a small karstic agricultural catchment, Southwest China

In order to quantify the sources and fluxes of DIC, the effects of the use of $\mathrm{N}$-fertilizers and acid deposition on carbonate weathering have been quantified by hydrochemistry and $\delta^{13} \mathrm{C}_{\mathrm{DIC}}$ of groundwater in Qingmuguan underground river system (QURS) - a small karstic agricultural catchment of Southwest China. The results show that: (1) the significant temporal variations for major element concentrations and $\delta^{13} \mathrm{C}_{\text {DIC }}$ of groundwater in different months were observed, especially, of which the groundwater showed significant high concentrations of $\mathrm{DIC}, \mathrm{Ca}^{2+}, \mathrm{Mg}^{2+}, \mathrm{NO}_{3}^{-}, \mathrm{SO}_{4}^{2-}$ and $\delta^{13} \mathrm{C}_{\mathrm{DIC}}$ in rainy season and fertilizing period in the QURS; (2) the contributions of carbonate dissolution by carbonic acid to total concentrations of $\left(\mathrm{Ca}^{2+}+\mathrm{Mg}^{2+}\right)$ and $\mathrm{HCO}_{3}^{-}$of groundwater in different months averaged $68.5 \%$ and $81.0 \%$, respectively. While the contributions of carbonate dissolution by nitric acid originated from the use of $\mathrm{N}$-fertilizers and atmospheric acid deposition to total concentrations of $\left(\mathrm{Ca}^{2+}+\mathrm{Mg}^{2+}\right)$ and $\mathrm{HCO}_{3}^{-}$of groundwater in different months averaged $11.1 \%$ and $6.7 \%$, respectively, and the contributions of carbonate dissolution by sulphuric acid originated from the atmospheric acid deposition to total concentrations of $\left(\mathrm{Ca}^{2+}+\mathrm{Mg}^{2+}\right)$ and $\mathrm{HCO}_{3}^{-}$of groundwater in different months averaged $20.4 \%$ and $12.3 \%$, respectively; (3) the $\delta^{13} \mathrm{C}_{\mathrm{DIC}}$ increased obviously with $\left(\mathrm{Ca}^{2+}+\mathrm{Mg}^{2+}\right) / \mathrm{HCO}_{3}^{-}$of groundwater in the rainy season and fertilizing period indicated that the use of $\mathrm{N}$-fertilizers and atmospheric acid deposition should be responsible for the elevated the $\delta^{13} \mathrm{C}_{\mathrm{DIC}}$ and the molar ratio of $\left(\mathrm{Ca}^{2+}+\mathrm{Mg}^{2+}\right) / \mathrm{HCO}_{3}^{-}$of groundwater in the QURS.

Key words: carbonate weathering, karst groundwater, agricultural activities, atmospheric acid deposition, Qingmuguan, Southwest China.
\end{abstract}

Izvleček UDK 552.54:551.3.053(513)
Yu Chen \& Yongjun Jiang Vpliv kmetijske dejavnosti in kis-
lih usedlin iz zraka na preperevanje karbonatov na majhnem
kraškem kmetijskem območju na jugozahodu Kitajske Da bi določili izvor in tok DIC (raztopljen anorganski ogljik) smo vrednotili učinek uporabe dušikovih gnojil in kislih usedlin na preperevanje karbonatov. Pri tem smo se poslužili hidrokemičnih postopkov in analize $\delta^{13} \mathrm{C}_{\mathrm{DIC}}$ podzemne vode $\mathrm{v}$ kraškem zaledju reke Quinmugan (QURS), ki je del manjšega kmetijskega območja na jugozahodu Kitajske. Rezultati so pokazali naslednje: (1) Izmerjene so bile opazne časovne spremembe $\mathrm{v}$ koncentraciji glavnih elementov in $\delta^{13} \mathrm{C}_{\text {DIC }} \mathrm{v}$ podzemni vodi $\mathrm{v}$ različnih mesecih; to je še posebej očitno $\mathrm{v}$ deževnem obdobju in času gnojenja, ko so bile zabeležene izrazito povečane koncentracije $\mathrm{DIC}, \mathrm{Ca}^{2+}, \mathrm{Mg}^{2+}, \mathrm{NO}_{3}^{-}, \mathrm{SO}_{4}^{2-}$ in $\delta^{13} \mathrm{C}_{\mathrm{DIC}}$; (2) Delež preperevanja karbonatov zaradi ogljikove kisline je glede na skupne koncentracije $\left(\mathrm{Ca}^{2+}+\mathrm{Mg}^{2+}\right)$ in $\mathrm{HCO}_{3}^{-}$ $\mathrm{v}$ podzemni vodi $\mathrm{v}$ različnih mesecih $\mathrm{v}$ povprečju znašal med $68,5 \%$ in $81,0 \%$. Medtem je delež preperevanja karbonatov zaradi dušikove kisline (posledica uporabe dušikovih gnojil in kislih usedlin iz zraka) glede na skupne koncentracije $\left(\mathrm{Ca}^{2+}+\mathrm{Mg}^{2+}\right)$ in $\mathrm{HCO}_{3}^{-} \mathrm{v}$ podzemni vodi $\mathrm{v}$ različnih mesecih v povprečju znašal med $11,1 \%$ in $6,7 \%$, delež preperevanja karbonatov zaradi žveplove kisline (posledica kislih usedlin iz zraka) glede na skupne koncentracije $\left(\mathrm{Ca}^{2+}+\mathrm{Mg}^{2+}\right)$ in $\mathrm{HCO}_{3}^{-} \mathrm{v}$ podzemni vodi v različnih mesecih pa je $\mathrm{v}$ povprečju znašal med $20,4 \%$ in $12,3 \%$; (3) Vsebnost $\delta^{13} \mathrm{C}_{\text {DIC }}$ v podzemni vodi se $\mathrm{v}$ času deževne sezone občutno poveča skupaj $\mathrm{z}$ razmerjem $\left(\mathrm{Ca}^{2+}+\mathrm{Mg}^{2+}\right) / \mathrm{HCO}_{3}^{-}$, obdobje gnojenja pa nakazuje, da uporaba dušikovih gnojil in usedanje kislin iz ozračja vplivajo na povišano vsebnost $\delta^{13} \mathrm{C}_{\text {DIC }}$ in molarno razmerje $\left(\mathrm{Ca}^{2+}+\mathrm{Mg}^{2+}\right) /$ $\mathrm{HCO}_{3}^{-} \mathrm{v}$ podzemni vodi v rečnem sistemu QURS.

Ključne besede: preperevanje karbonatov, kraška podzemna voda, kmetijske dejavnosti, kisle usedline iz zraka, Qingmuguan, jugozahodna Kitajska.

\footnotetext{
${ }^{1}$ School of Geographical Sciences, Southwest University, Chongqing 400715, China;

${ }^{2}$ Karst Environment Laboratory, Southwest University, Chongqing 400715, China.

Yu Chen, School of Geographical Sciences, Southwest University, 400715 Chongqing, China; e-mail: chenyu192781@163.com ${ }^{*}$ Corresponding author:

Yongjun Jiang, School of Geographical Sciences, Southwest University, 400715 Chongqing, China; e-mail: jiangjyj@swu.edu.cn Received/Prejeto: 18.03.2016
} 


\section{INTRODUCTION}

The geological-environmental characteristics of karst hydrological systems result in a highly vulnerable system, which is considerably sensitive to external environmental changes. While the increasing environmental pollution, both deliberate and unintentional forms as consequence of human activities, has to a great extent spoiled sensitive karst hydrological systems in Southwest China (Liu et al. 2006, 2008; Jiang et al. 2008, 2009a, 2009b; Jiang 2012; $\mathrm{Pu}$ et al. 2011). Concentrations of nitrate and sulphate of karst groundwater in southwest China increase notably as a result of large amount of chemical fertilizers used in agriculture (Liu et al. 2006; Jiang et al. 2008, 2009a, 2009b; Jiang 2012; Pu et al. 2011) and acid deposition (Li et al. 2008, 2010), which could not only influence the quality of karst groundwater, as well as the carbonate weathering process related to the global carbon cycle.

Conventionally, the DIC in karst groundwater is dominantly derived from carbonate dissolution by carbonic acid (Eq. 1), which forms from reaction of soil or atmospheric $\mathrm{CO}_{2}$ with water.

$$
\begin{aligned}
& \left(\mathrm{Ca}_{1-\mathrm{x}} \mathrm{Mg}_{\mathrm{x}}\right) \mathrm{CO}_{3}+\mathrm{H}_{2} \mathrm{O}+\mathrm{CO}_{2} \rightarrow(1-\mathrm{x}) \mathrm{Ca}^{2+}+ \\
& \mathrm{xMg}^{2+}+2 \mathrm{HCO}_{3}^{-}
\end{aligned}
$$

In this case, half of the DIC (generally, bicarbonate is the dominant DIC species in karst groundwater) in karst groundwater derived from soil/atmospheric $\mathrm{CO}_{2}$ constitutes an important sink of atmospheric $\mathrm{CO}_{2}$.

However, recently increases in the inorganic carbon flux in karst groundwater have been linked to agricultural activities and acid precipitation (Semhi et al. 2000; Calmels et al. 2007; Li et al. 2008, 2010; Perrin et al. 2008; Barnes \& Raymond 2009; Ali \& Atekwana 2011; Gandois et al. 2011; Jiang 2013; Yue et al. 2015).

The consequence of the use of nitrogen fertilizers (usually in the form of $\left(\mathrm{CO}\left(\mathrm{NH}_{2}\right)_{2}\right),\left(\mathrm{NH}_{4}\right)_{2} \mathrm{SO}_{4}, \mathrm{NH}_{3}$ and $\left(\mathrm{NH}_{4}\right)_{2} \mathrm{PO}_{4}$, is the release of protons in the soil during the nitrification process. $\mathrm{N}$ fertiliser oxidation produces two protons for every nitrified ammonium ion and then enhances carbonate weathering. These processes can be expressed as following equations:

$$
\begin{aligned}
& \mathrm{NH}_{4}^{+}+2 \mathrm{O}_{2}=\mathrm{NO}_{3}^{-}+2 \mathrm{H}^{+}+\mathrm{H}_{2} \mathrm{O} \\
& \mathrm{CaCO}_{3}+\mathrm{H}^{+}=\mathrm{Ca}^{2+}+\mathrm{HCO}_{3}^{-}
\end{aligned}
$$

$\mathrm{NH}_{4}^{+}+2 \mathrm{O}_{2}+2\left(\mathrm{Ca}_{1-\mathrm{x}} \mathrm{Mg}_{\mathrm{x}}\right) \mathrm{CO}_{3}=\mathrm{NO}_{3}^{-}+$

$2(1-\mathrm{x}) \mathrm{Ca}^{2+}+2 \mathrm{xMg}^{2+}+2 \mathrm{HCO}_{3}^{-}+\mathrm{H}_{2} \mathrm{O}$

Acid deposition, including reactive $\mathrm{N}$ and sulfate, has dramatically increased worldwide in the past few decades, of which more than one third of the territory in China (Tang et al. 2010), especially in Southwest China, is suffering from acid deposition. Anthropogenic $\mathrm{Nr}$ is released to the atmosphere either as nitrogen oxides (NOx), mainly from combustion, or as ammonia $\left(\mathrm{NH}_{3}\right)$, mainly from agriculture (Dentener et al. 2006; Paulot et al. 2013). NOx is oxidized in the atmosphere to nitric acid $\left(\mathrm{HNO}_{3}\right)$ and ammonia can be transformed into $\mathrm{NH}_{4}^{+}$ through chemical reactions and then can be nitrified and produce proton. Sulfate is released to the atmosphere as SOx, predominately from sulfur emissions (fossil fuel combustion) (Dentener et al. 2006), and SOx can be oxidized in the atmosphere to sulfuric acid $\left(\mathrm{H}_{2} \mathrm{SO}_{4}\right)$. Thus, acid deposition can impact carbonate weathering. These processes can be expressed as following equations:

$$
\begin{aligned}
& \left(\mathrm{Ca}_{1-\mathrm{x}} \mathrm{Mg}_{\mathrm{x}}\right) \mathrm{CO}_{3}+\mathrm{HNO}_{3} \rightarrow(1-\mathrm{x}) \mathrm{Ca}^{2+}+\mathrm{xMg}^{2+}+ \\
& \mathrm{NO}_{3}^{-}+\mathrm{HCO}_{3}^{-}
\end{aligned}
$$

$2\left(\mathrm{Ca}_{1-\mathrm{x}} \mathrm{Mg}_{\mathrm{x}}\right) \mathrm{CO}_{3}+\mathrm{H}_{2} \mathrm{SO}_{4} \rightarrow 2(1-\mathrm{x}) \mathrm{Ca}^{2+}+$ $2 \mathrm{xMg}^{2+}+\mathrm{SO}_{4}^{2-}+2 \mathrm{HCO}_{3}^{-}$

In these cases, carbonate dissolution by nitric and sulphuric acids are resulting in greater DIC export, which is derived from the carbonate rather than from the $\mathrm{CO}_{2}$ sequestration. Such enhanced carbonate weathering by anthropogenic acidity inputs could not only influence the element fluxes to riverine systems, as well as the global carbon cycle.

Thus, based on these knowledge, this paper presented the results of chemical analysis for the concentrations of major ions, DIC and $\delta^{13} \mathrm{C}$-DIC of groundwater, and discussed: (1) to quantify the sources and fluxes of DIC in groundwater, and (2) to evaluate the effects of $\mathrm{N}$-fertilizers and acid deposition on carbonate weathering in a small karstic agricultural catchment of Southwest China. 


\section{STUDY AREA}

The Qingmuguan Underground River System (QURS) is located at the west of Chongqing municipality, Southwest China (Fig. 1). The underground drainage area of the system is approximately $11.4 \mathrm{~km}^{2}$. The elevation of QURS is between 320 640 $\mathrm{m}$ above average sea level. The climate is primarily subtropical monsoonal with a mean annual precipitation of $1100 \mathrm{~mm}$ and a mean air temperature of $16.5^{\circ} \mathrm{C}$. The monsoonal climate results in a rainy season from April to October and a dry season from November to March.

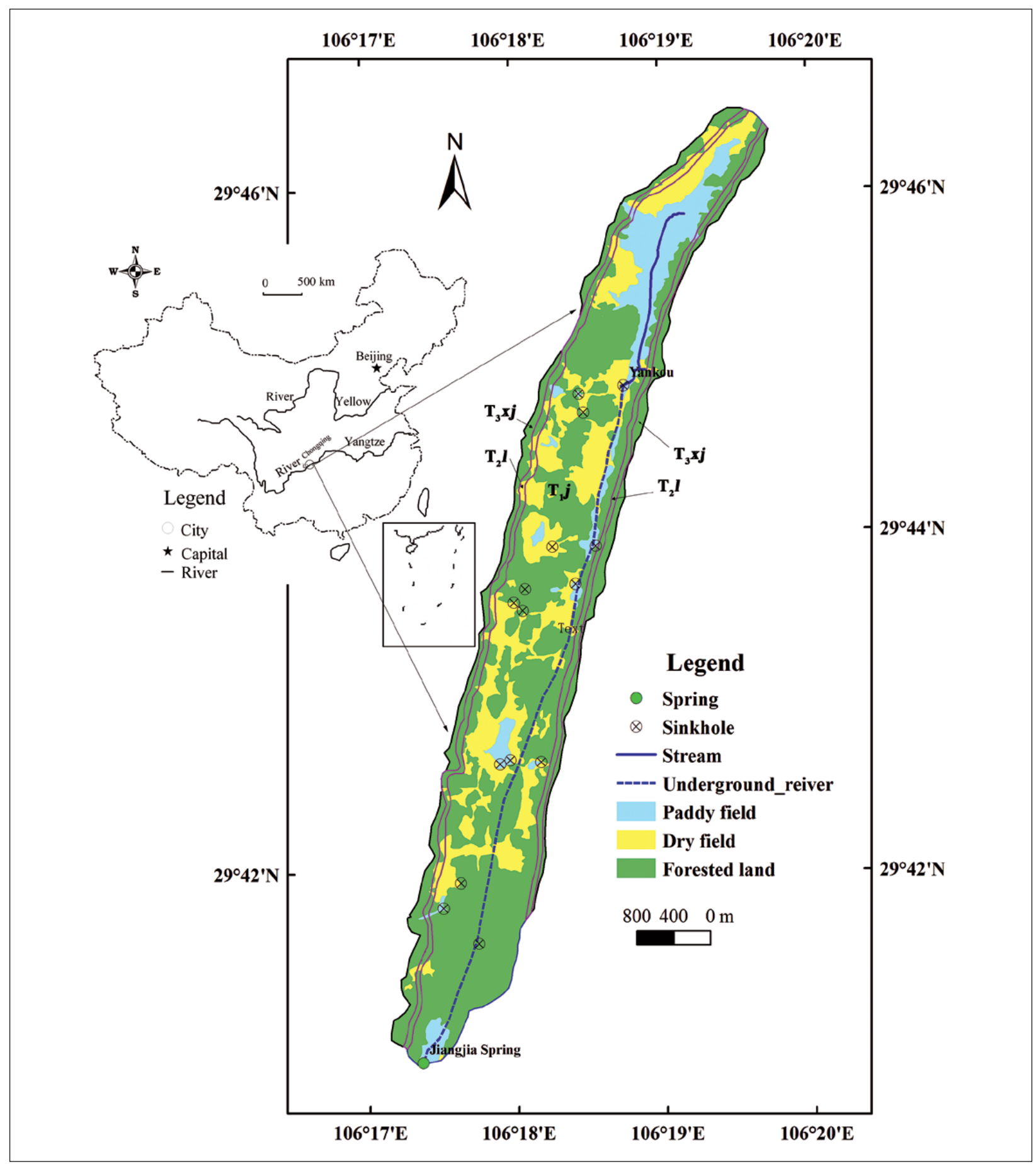

Fig. 1: Location, hydrogeological and land use map in the QURS. 


\section{GEOLOGY AND HYDROGEOLOGY}

The geologic layers of the study area are shown in Fig. 1. The QURS lies in the middle part of the Wentangxia anticline, Chongqing, and the aquifers are mainly underlain by Lower and Middle Triassic strata (Fig. 1). Carbonate rocks (limestone) cover an area of $10 \mathrm{~km}^{2}$ or about 88 $\%$ of the total area. The strata of the anticlinal axis are carbonate rocks of the Lower Triassic Jialingjiang Formation $\left(\mathrm{T}_{1} \mathrm{j}\right)$, with limestone being a major lithology, whereas anticlinal wings are carbonate rocks of the Middle Triassic Leikoupo Formation $\left(\mathrm{T}_{2} l\right)$ and sandstones with some coal seams of the Upper Triassic Xujiahe Formation $\left(\mathrm{T}_{3} x j\right)$. Yellow-green calcareous clay rocks of the Lower Leikoupo $\left(\mathrm{T}_{2} l\right)$ overlie the Jialingjiang Group $\left(\mathrm{T}_{1} \mathrm{j}\right)$. No sulfate evaporates (gypsum and anhydrite) are exposed in the study area. Due to the banded distribution of carbonate rocks and the presence of relatively impermeable sandstone at two wings combined with a vertical patulous cranny which was well developed in the anticlinal core, basic conditions exist for a formation of a karst trough valley and the development of a karst groundwater system. There are many depressions, caves, dolines and sinkholes in the catchment. In the upper stream, the surface water in Ganjiacao depression, which is the biggest depression, recharges the QURS via Yankou sinkhole. The Qingmuguan Underground River developed in the core of the karst trough valley and flowed along anticlinal axis (Lower Triassic Jialingjiang formation) in a NE-SW direction with a total length of $7.8 \mathrm{~km}$. In the downstream reach of the QURS, the Jiangiia spring discharges the groundwater of the QURS. High-resolution tracer tests in the catchment indicated a single conduit between Yankou sinkhole and Jiangjia spring (Fig. 1) (He et al. 2010), and the Jiangjia spring is the only outlet of the hydrological system. Flow rates of the spring have large variations around a year from 0.002 to $3.5 \mathrm{~m}^{3} / \mathrm{s}$, with an average of $20.5 \mathrm{l} / \mathrm{s}$. The spring water is used by individual households.

\section{LAND USE PATTERN, VEGETATION, SOIL AND AGRICULTURAL PRACTICES}

There are three land use categories (Fig. 1): forested land, paddy land and dry land. The percentages of land use were 64.9 for forested, 11.4 for paddy land and 23.7 for dry land, respectively. Paddy fields are mainly distributed in the Ganjiacao depression, and dry fields are scattered around the bottom of the valley. The crops are rice in paddy field, potato and vegetables in dry field.

Vegetation is predominantly subtropical evergreen broadleaved forests. Those plants and crops are $\mathrm{C}_{3}$ photosynthetic type.

The dominant types of soils are mainly limestone soil and yellow soil derived from carbonate rocks and sandstones, respectively. Paddy soil are scattered in the depressions.

Farmers principally spread chemical fertilizers on soils in spring and summer seasons, mainly compound fertilizers of the N-P-K type and straight fertilizers such as urea $\left(\mathrm{CO}\left(\mathrm{NH}_{2}\right)_{2}\right), \mathrm{NH}_{4} \mathrm{HCO}_{3}$ and ammonium sulphate $\left(\left(\mathrm{NH}_{4}\right)_{2} \mathrm{SO}_{4}\right)$. Typical amounts of chemical fertilizers used in the catchment are $1200 \mathrm{~kg} \mathrm{ha}^{-1} \mathrm{yr}^{-1}$ for rice, $600 \mathrm{~kg} \mathrm{ha}^{-1} \mathrm{yr}^{-1}$ for vegetables. Because soil $\mathrm{pH}$ and carbonate content are high, buffering with lime is not practiced.

\section{SAMPLES AND ANALYSES}

The rainfall was collected from the $\mathrm{HOBO}$ weather station (made by OnSET Ltd., USA) installed in the catchment, which the resolution of rainfall was $0.2 \mathrm{~mm}$ with a time internal of $15 \mathrm{~min}$. The discharge, water temperature, $\mathrm{pH}$ and specific conductivity of groundwater were monitored at $15 \mathrm{~min}$ intervals using a Greenspan CTDP 300 multi-channel data logger.

Monthly samples of groundwater were collected for analysis of major hydrochemical components and isotope in laboratory in 2013. Rainwater was collected during 3 events in the catchment from May to July, 2013.

Temperature, $\mathrm{pH}$, specific conductivity (SC, at $25^{\circ} \mathrm{C}$ ) and dissolved oxygen (DO) of groundwater and rainwater were measured in the field using a WTW multiparameter probe (Multiline P3 PH/LF-SET) with reso- lutions of $0.1{ }^{\circ} \mathrm{C}, 0.1,1 \mu \mathrm{Scm}^{-1}$ and $0.1 \mathrm{mg} \mathrm{L}^{-1}$, respectively. $\mathrm{NH}_{4}^{+}$of groundwater and rainwater was measured in the field using a D8500 water quality multimeter ( $\mathrm{HACH}$, America), with resolution of $0.001 \mathrm{mg} / \mathrm{l} . \mathrm{Ca}^{2+}$ and $\mathrm{HCO}_{3}^{-}$were determined by a test kit with a titration pipette (Aquamerck) in the field with resolutions of $2 \mathrm{mg} / \mathrm{l}$ and $0.1 \mathrm{mmol} / \mathrm{l}$, respectively.

Water samples of the spring and rain were collected by injection syringes and were immediately filtered into pre-rinsed plastic containers $(1 \mathrm{~L})$ with $0.45 \mu \mathrm{m}$ filter membranes for ion analyses, one of which was acidified to $\mathrm{pH}<2$ with $\mathrm{HNO}_{3}$ to preserve cation concentrations. To limit gas exchange, the plastic containers were cooled with ice. Samples for the stable carbon isotope of dissolved inorganic carbon $\left(\delta^{13} \mathrm{C}_{\mathrm{DIC}}\right)$ analysis were filtered 
into $10 \mathrm{~mL}$ tubes with $0.2 \mu \mathrm{m}$ cellulose-acetate filters. Soon after collection, these samples were preserved using three drops of a saturated solution of $\mathrm{HgCl}_{2}$ to prevent microbial alteration. All samples were kept refrigerated (below $4{ }^{\circ} \mathrm{C}$ ) until analysis.

Three representative plant samples (including the root, stem and leaf), rice, bamboo and Cyclobalanopsis, were collected in the catchment. Meanwhile, three soil $\mathrm{CO}_{2}$ samples were collected, using a capillary tube reaching in $0.4-0.8 \mathrm{~m}$ depth and an evacuated glass vessel with Kontes valves, under the corresponding plants. Also, two limestone samples were collected from Lower Trissic Jialingjiang formation and Middle Triassic Leikoupo Formation, respectively.

Concentrations of major cations and anions were measured with inductively coupled plasma optical emission spectrometry (ICP-OES) with a resolution of $0.01 \mathrm{mg} / \mathrm{l}$ and ion chromatography (IC) with a resolution of $0.01 \mathrm{mg} / \mathrm{l}$, respectively, at the Water Environmental Laboratory of Southwest University. The precision of the IC and ICP analyses was within $\pm 5 \%$ for major elements.

For $\delta^{13} \mathrm{C}_{\mathrm{DIC}}$, using the modified method of Atekwana and Krishnamurthy (1998) for stable carbon isotope analysis of dissolved inorganic carbon, a $10 \mathrm{~mL}$ water sample was injected by syringe into glass bottles that were pre-filled with $1 \mathrm{~mL} 85 \%$ phosphoric acid and magnetic stir bars. The $\mathrm{CO}_{2}$ was extracted and purified after cryogenic removal of $\mathrm{H}_{2} \mathrm{O}$ using a liquid nitrogenethanol trap. Finally, the $\mathrm{CO}_{2}$ was transferred cryogenically into a tube for isotope measurement.

Plant samples were ultrasonically cleaned for $15 \mathrm{~min}$ in deionized water, and dried in an oven at $50{ }^{\circ} \mathrm{C}$ for $48 \mathrm{~h}$. Then, the plant samples were ground into powder with diameters less than $150 \mu \mathrm{m}$ to ensure homogeneity, of which 1 to $2 \mathrm{mg}$ was placed into stannum cups for carbon isotope analysis.

All analyses for $\delta^{13} \mathrm{C}$ were done at the Geochemistry Laboratory of Southwest University. The carbon isotopic compositions of soil organic matter and plants were determined using an elemental analyzer coupled to an isotope-ratio mass spectrometer (EA-IRMS), and the carbon isotopic compositions of DIC, soil $\mathrm{CO}_{2}$ and carbonate were determined using Gas Bench-linked with Delta V Plus gas stable isotope-ratio mass spectrometer (Gasbench-IRMS). The results were expressed on a conventional permil scale with respect to the Vienna Pee Dee Belemnite (V-PDB) standard. The overall experimental accuracy for $\delta^{13} \mathrm{C}$ during this study was $\pm 0.2 \%$.

\section{RESULTS AND DISCUSSION}

\section{THE $\delta^{13} \mathrm{C}$ OF LIMESTONE, PLANTS AND SOIL ORGANIC MATTER}

Isotopic compositions $\left(\delta^{13} \mathrm{C}\right)$ of limestone, plants and soil $\mathrm{CO}_{2}$ are shown in Tab. 1 . The $\delta^{13} \mathrm{C}$ of limestone from Jinaglingjiang and Leikoupo information was $0.2 \%$ and $0.3 \%$, respectively, consistent with typical values of marine limestone. The $\delta^{13} \mathrm{C}$ of plants varied from $-26.6 \%$

Tab. 1: Isotopic composition $\left(\delta^{13} \mathrm{C}\right)$ of limestone, plants and soil $\mathrm{CO}_{2}$ in QURS.

\begin{tabular}{lll}
\hline Sample type & & $\delta^{13} \mathrm{C}(\%)$ \\
\hline Limestone & Jialingjiang formation of Lower & 0.2 \\
& Trissic limestone $\left(\mathrm{T}_{\mathrm{j}} \mathrm{j}\right)$ & 0.3 \\
& Leikoupo Formation of Middle & \\
\cline { 2 - 3 } Plant & Triassic limestone $\left(\mathrm{T}_{2} \mathrm{l}\right)$ & -28.6 \\
\cline { 2 - 3 } & Rice & -28.4 \\
& Bamboo & -26.6 \\
\hline \multirow{3}{*}{ Soil $\mathrm{CO}_{2}$} & Cyclobalanopsis & -24.3 \\
& Soil $\mathrm{CO}_{2}$ in a Rice field & -23.1 \\
& Soil $\mathrm{CO}_{2}$ in a Bamboo field & -22.6 \\
\hline & Soil $\mathrm{CO}_{2}$ in a Cyclobalanopsis field & \\
\hline
\end{tabular}

to $-28.6 \%$ with an average value of $-27.9 \%$, consistent with the major vegetation type using the $\mathrm{C}_{3}$ carbon fixation pathway in the catchment. The $\delta^{13} \mathrm{C}$ of soil $\mathrm{CO}_{2}$ ranged from $-22.6 \%$ to $-24.3 \%$ with an average value of $-23.3 \%$.

\section{THE $\delta^{13} \mathrm{C}_{\text {DIC }}$ IN GROUNDWATER}

From the range of $\mathrm{pH}$ values it can be deduced that bicarbonate $\left(\mathrm{HCO}_{3}^{-}\right)$is the dominant DIC species of the groundwater in the catchment. Therefore, concentrations of total inorganic carbon are expressed as $\mathrm{HCO}_{3}^{-}$in this article. As shown in Tab. 2, the $\delta^{13} \mathrm{C}_{\mathrm{DIC}}$ of groundwater varied from $-12.4 \%$ to $-10.1 \%$ in different months, with a mean value of $-11.2 \%$ in 2013 in the catchment. Also, as shown in Fig. 2, obvious positive $\delta^{13} C_{\text {DIC }}$ values of groundwater were observed in the rainy season and fertilizing period, and negative $\delta^{13} \mathrm{C}_{\mathrm{DIC}}$ values of groundwater were observed in the winter, suggesting the $\delta^{13} \mathrm{C}_{\mathrm{DIC}}$ of groundwater was controlled by different geochemical processes in different seasons in the QURS. 


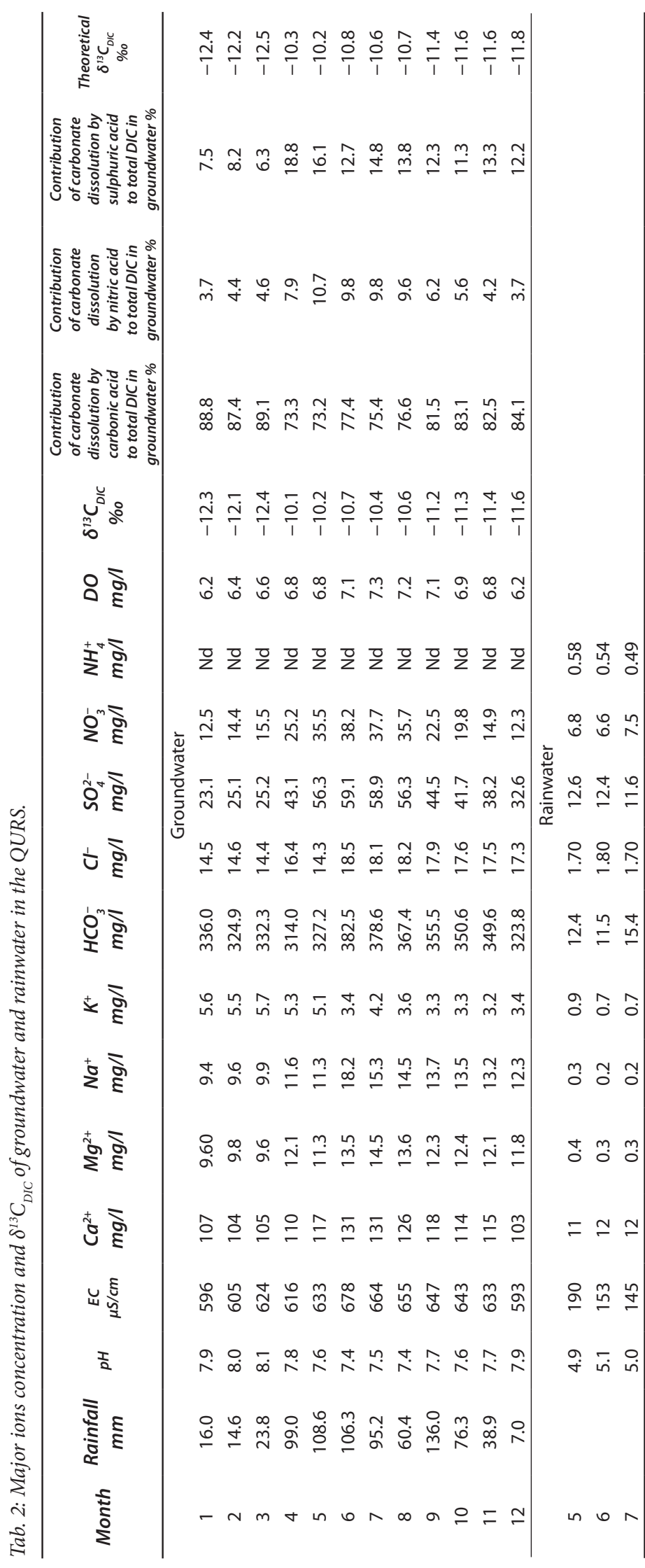

\section{CHEMICAL CHARACTERISTICS OF GROUNDWATER AND RAINWATER}

As shown in Tab. 2, the $\mathrm{pH}$ values of groundwater samples in the QURS ranged from 7.4 to 8.1, averaging 7.7. The $\mathrm{Ca}^{2+}$ concentrations in groundwater varied from $103 \mathrm{mg} / \mathrm{l}$ to $131 \mathrm{mg} / \mathrm{l}$, with a mean value of $115 \mathrm{mg} / \mathrm{l}$. The $\mathrm{Mg}^{2+}$ concentrations varied from $9.6 \mathrm{mg} / \mathrm{l}$ to $14.5 \mathrm{mg} / \mathrm{l}$, with a mean value of $11.9 \mathrm{mg} / \mathrm{l} . \mathrm{Ca}^{2+}$ and $\mathrm{Mg}^{2+}$ dominate the cation concentrations in groundwater, accounted for $82-86 \%$ of the total cations in groundwater. The $\mathrm{NH}_{4}^{+}$was not detected in the groundwater samples. $\mathrm{HCO}_{3}^{-}$was the most abundant anions, and its concentrations ranged from $314.0 \mathrm{mg} / \mathrm{l}$ to $382.5 \mathrm{mg} / \mathrm{l}$, averaging $345.2 \mathrm{mg} / \mathrm{l}$. The $\mathrm{SO}_{4}^{2-}$ and $\mathrm{NO}_{3}^{-}$concentrations varied dramatically, ranging from $23.1 \mathrm{mg} / \mathrm{l}$ to $59.1 \mathrm{mg} / \mathrm{l}$ and $12.3 \mathrm{mg} / \mathrm{l}$ to $38.2 \mathrm{mg} / \mathrm{l}$ in different months, with a mean concentration of $42.0 \mathrm{mg} / \mathrm{l}$ and $23.7 \mathrm{mg} / \mathrm{l}$, respectively. The $\mathrm{Cl}^{-}$ranged from $14.3 \mathrm{mg} / \mathrm{l}$ to $18.5 \mathrm{mg} / \mathrm{l}$, with a mean concentration of $16.6 \mathrm{mg} / \mathrm{l}$.

Rainwater showed lower $\mathrm{pH}$ values, ranging from 4.9 to 5.1 , typically characterized by acid rain. Concentrations of $\mathrm{Ca}^{2+}, \mathrm{SO}_{4}^{2-}$ and $\mathrm{NO}_{3}^{-}$in rainwater ranged from $11 \mathrm{mg} / \mathrm{l}$ to $12 \mathrm{mg} / \mathrm{l}, 11.6$ $\mathrm{mg} / \mathrm{l}$ to $12.6 \mathrm{mg} / \mathrm{l}$ and $6.6 \mathrm{mg} / \mathrm{l}$ to $7.5 \mathrm{mg} / \mathrm{l}$, respectively. And other ions concentrations were very low in rainwater.

Meanwhile, as shown in Fig. 2, pH showed lower values in rainy season and higher values in the winter, indicating $\mathrm{pH}$ was impacted by the dilution effect of rainwater with lower $\mathrm{pH}$ in the rainy season. In contrast, the concentrations of $\mathrm{Ca}^{2+}, \mathrm{Mg}^{2+}, \mathrm{HCO}_{3}^{-}, \mathrm{NO}_{3}^{-}$and $\mathrm{SO}_{4}^{2-}$ in groundwater tended to be enriched in rainy season, and the dilution effect of rainfall has not been observed in these ions of groundwater, suggesting these ions were impacted by some geochemical processes which are different from other seasons.

\section{RELATIONSHIP BETWEEN $\left(\mathrm{Ca}^{2+}+\mathrm{Mg}^{2+}\right)$} AND $\mathrm{HCO}_{3}^{-}$IN GROUNDWATER

As shown in Figure 3a, the molar ratio between $\left(\mathrm{Ca}^{2+}+\mathrm{Mg}^{2+}\right)$ and $\mathrm{HCO}_{3}^{-}$of groundwater in the QURS varied from 0.56 to 0.63 with a mean value of 0.60 in different months, which higher molar ratio between $\left(\mathrm{Ca}^{2+}+\mathrm{Mg}^{2+}\right.$ and $\mathrm{HCO}_{3}^{-}$of groundwater were observed in the rainy season and fertilizing period. As indicated by Equation (1), the molar ratio between $\left(\mathrm{Ca}^{2+}+\mathrm{Mg}^{2+}\right)$ and $\mathrm{HCO}_{3}^{-}$released into the groundwater should be 0.5 , suggesting that carbonate dissolution is controlled by natural processes involving carbonic 


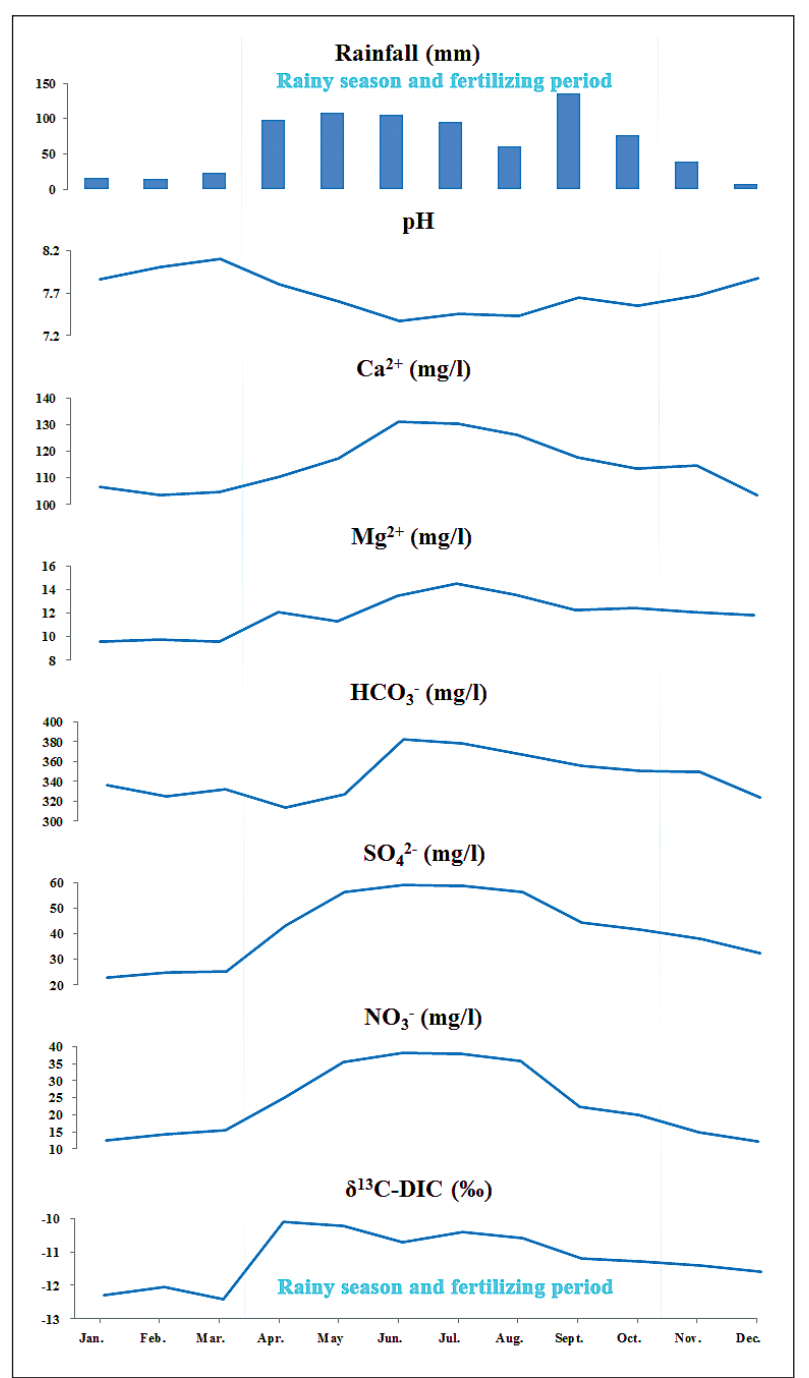

Fig. 2: Seasonal variations of rainfall and hydrogeochemistry of groundwater in 2013.

acid. However, as indicated by Equation (4), (5) and (6), the molar ratio between $\left(\mathrm{Ca}^{2+}+\mathrm{Mg}^{2+}\right)$ and $\mathrm{HCO}_{3}^{-}$released into the groundwater should be 1 , suggesting that carbonate dissolution is governed by sulphuric/nitric acid. These suggested that carbonic acid could probably not be a unique weathering agent in the catchment. Mean-

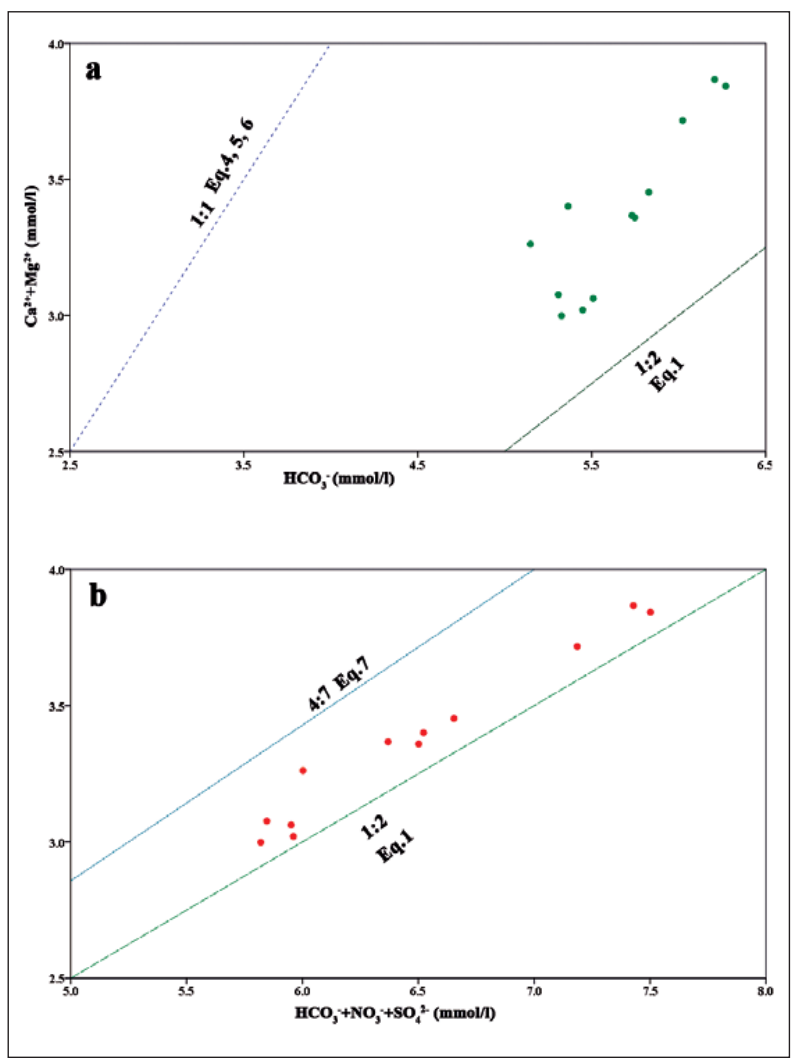

Fig. 3: Cross plot of $\left(\mathrm{Ca}^{2+}+\mathrm{Mg}^{2+}\right)$ vs. $\mathrm{HCO}_{3}^{-}(a)$ and $\left(\mathrm{Ca}^{2+}+\mathrm{Mg}^{2+}\right)$ vs. $\left(\mathrm{HCO}_{3}^{-}+\mathrm{NO}_{3}^{-}+\mathrm{SO}_{4}^{2-}\right)($ b) in groundwater.

while, as stated in section 4.3 , higher concentrations of $\mathrm{Ca}^{2+}, \mathrm{Mg}^{2+}, \mathrm{HCO}_{3}^{-}, \mathrm{NO}_{3}^{-}$and $\mathrm{SO}_{4}^{2-}$ of groundwater were observed the rainy season and fertilizing period, suggesting that among the different sources of protons mentioned in the introduction, fertilizers as well as atmospheric acid deposition may play an important role in the carbonate weathering in the catchment. Therefore, the questions arised whether those elements in groundwater originated from carbonate dissolution by carbonic and sulphuric/nitric acids and to which extent of carbonate dissolution were influenced by different acids in different months.

\section{DISCUSSION}

\section{ATMOSPHERIC INPUTS}

Compared to groundwater, the rainwater showed very low concentrations of $\mathrm{Ca}^{2+}, \mathrm{Mg}^{2+}$ and $\mathrm{HCO}_{3}^{-}$, however, high concentrations of $\mathrm{NO}_{3}^{-}$and $\mathrm{SO}_{4}^{2-}$ in the catchment. Therefore, it might be concluded that $\mathrm{Ca}^{2+}, \mathrm{Mg}^{2+}$ and
$\mathrm{HCO}_{3}^{-}$supplied by atmospheric inputs are low, but nitrate and sulfate inputs are significant. The highest values of nitrate and sulfate were observed during local fertilizer spreading period, suggesting that they partly originate from fertilizer inputs. Meanwhile, a significant amount 
of $\mathrm{NH}_{4}^{+}$is supplied to the catchment by rainwater, but $\mathrm{NH}_{4}^{+}$was not detected in groundwater, which could be presumably nitrified in the catchment by soil bacteria and used by plants.

\section{HYDROCHEMISTRY OF GROUNDWATER: CARBONATE DISSOLUTION BY CARBONIC ACID VERSUS SULPHURIC AND NITRIC SULPHURIC ACIDS}

As atmospheric inputs of $\mathrm{Ca}^{2+}, \mathrm{Mg}^{2+}$ and $\mathrm{HCO}_{3}^{-}$are very low, and the silicate weathering originated from sandstone with slow dissolution can be neglected, the concentrations of $\mathrm{Ca}^{2+}, \mathrm{Mg}^{2+}$ and $\mathrm{HCO}_{3}^{-}$were mainly originated from carbonate dissolution in the catchment. If the contributions of carbonic, sulphuric and nitric acids in equimolar amounts to the carbonate dissolution were considered, carbonate dissolution becomes (Eq. 7):

$$
\begin{aligned}
& 4\left(\mathrm{Ca}_{1-\mathrm{x}} \mathrm{Mg}_{\mathrm{x}}\right) \mathrm{CO}_{3}+\mathrm{H}_{2} \mathrm{CO}_{3}+\mathrm{HNO}_{3}+\mathrm{H}_{2} \mathrm{SO}_{4} \rightarrow \\
& 4(1-\mathrm{x}) \mathrm{Ca}^{2+}+4 \mathrm{xMg}^{2+}+5 \mathrm{HCO}_{3}^{-}+\mathrm{NO}_{3}^{-}+\mathrm{SO}_{4}^{2-}
\end{aligned}
$$

In this case, the molar ratio between $\left(\mathrm{Ca}^{2+}+\mathrm{Mg}^{2+}\right)$ and $\mathrm{HCO}_{3}^{-}$, and $\left(\mathrm{Ca}^{2+}+\mathrm{Mg}^{2+}\right)$ and $\left(\mathrm{HCO}_{3}^{-}+\mathrm{NO}_{3}^{-}+\mathrm{SO}_{0}^{2-}\right)$ in groundwater should be $4 / 5(0.8)$ and 4/7 (0.571). However, the molar ratio between $\left(\mathrm{Ca}^{2+}+\mathrm{Mg}^{2+}\right)$ and $\mathrm{HCO}_{3}^{-}$, $\left(\mathrm{Ca}^{2+}+\mathrm{Mg}^{2+}\right)$ and $\left(\mathrm{HCO}_{3}^{-}+\mathrm{NO}_{3}^{-}+\mathrm{SO}_{4}^{2-}\right)$ of groundwater in different varied from 0.56 to 0.63 with a mean value of 0.60 , and from 0.51 to 0.54 with a mean value of 0.52 (Figs. $3 \mathrm{a}$ and $3 \mathrm{~b}$ ), which deviate from the expected the molar ratio of 0.8 and 0.57 , respectively, indicating carbonate dissolution in those groundwaters controlled by carbonic, sulphuric and nitric acids in different ratios. Meanwhile, it could be assumed that all $\mathrm{NO}_{3}^{-}$in groundwater could be derived from the nitrification of fertilizer and atmospheric $\mathrm{NH}_{4}^{+}$, and oxidation of atmospheric $\mathrm{NOx}$, due to other $\mathrm{NO}_{3}^{-}$sources in the catchment.

Thus, based on the (1), (5) and (6), the concentrations of $\left[\mathrm{Ca}^{2+}+\mathrm{Mg}^{2+}\right]$ and $\mathrm{HCO}_{3}^{-}$in groundwater resulted from the carbonate dissolution by carbonic, nitric and sulphuric acids can be calculated by following equations:

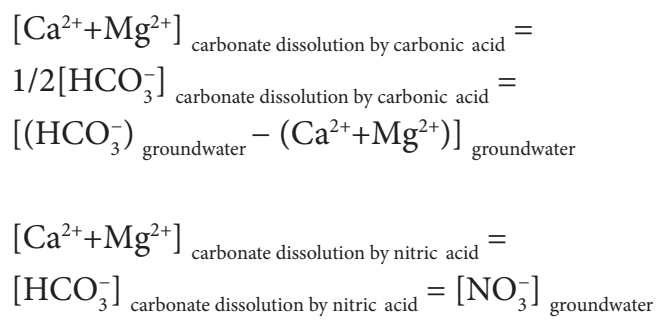

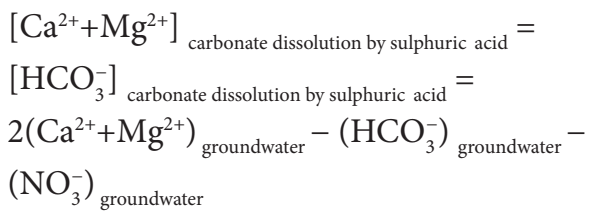

The calculated results are presented in Tab. 2. The contributions of carbonate dissolution by carbonic acid to total concentrations of $\left(\mathrm{Ca}^{2+}+\mathrm{Mg}^{2+}\right)$ and $\mathrm{HCO}_{3}^{-}$of groundwater in different months varied from $57.7 \%$ to $80.4 \%$ with mean percentage of $68.5 \%$, and from $73.2 \%$ to $89.1 \%$ with a mean percentage of $81 \%$, respectively. While the contributions of carbonate dissolution by nitric and sulphuric acids to total concentrations of $\left(\mathrm{Ca}^{2+}+\mathrm{Mg}^{2+}\right)$ and $\mathrm{HCO}_{3}^{-}$of groundwater in different months varied from $6.4 \%$ to $16.8 \%$ with a mean percentage of $11.1 \%$, and $3.7 \%$ to $10.7 \%$ with a mean percentage of $6.7 \%$, and from $11.3 \%$ to $29.7 \%$ with a mean percentage of $20.4 \%$ and $6.3 \%$ to $18.8 \%$ with a mean percentage of $12.3 \%$, respectively. Especially, the contributions of carbonate dissolution by carbonic acid to total concentrations of $\left(\mathrm{Ca}^{2+}+\mathrm{Mg}^{2+}\right)$ and $\mathrm{HCO}_{3}^{-}$of groundwater averaged only $63 \%$ and $77 \%$, while the contributions of carbonate dissolution by nitric and sulphuric acids to total concentrations of $\left(\mathrm{Ca}^{2+}+\mathrm{Mg}^{2+}\right)$ and $\mathrm{HCO}_{3}^{-}$of groundwater averaged $37 \%$ and $23 \%$ in rainy season and fertilizing period (from Apr. to Oct.). Therefore, based on the hydrochemical data, it can be concluded that carbonate dissolution was not only controlled by carbonic acid, but also by sulphuric and nitric acids introduced by the use of $\mathrm{N}$-fertilizers and atmospheric acid deposition in the catchment.

\section{THE $\delta^{13} \mathrm{C}_{\text {DIC }}$ IN GROUNDWATER: CARBONATE DISSOLUTION BY CARBONIC ACID VERSUS NITRIC AND SULPHURIC ACIDS}

Because the contribution of atmospheric $\mathrm{CO}_{2}$ to the DIC of groundwater was minor due to the high partial pressure of $\mathrm{CO}_{2}$ in groundwater, the DIC of groundwater in the catchment had two primary sources, soil $\mathrm{CO}_{2}$ and carbonate bedrock. The $\delta^{13} \mathrm{C}$ of soil $\mathrm{CO}_{2}$ and limestone averaged $-23.3 \%$ and $0.25 \%$, respectively. Meanwhile, groundwater showed higher DO (Dissolved oxygen) concentrations in different months, indicating it is an open karst system. In general, the fractionation of the carbon isotope composition was around $+9 \%$ between soil gas $\mathrm{CO}_{2}$ and $\mathrm{HCO}_{3}^{-}$(Deines 2004; Zhang et al. 1995). Therefore, DIC in groundwater originated from carbonate dissolving by $\mathrm{CO}_{2}$ in the catchment was expected to have $\delta^{13} \mathrm{C}_{\text {DIC }}$ value of around $-14 \%$. While the $\delta^{13} \mathrm{C}_{\text {DIC }}$ had identical values to the $\delta^{13} \mathrm{C}$ of carbonate $(0.25 \%$ ) which DIC was derived from carbonate dissolving by sulfur acid or nitric acid. Thus, the $\delta^{13} \mathrm{C}_{\text {DIC }}$ in ground- 
water approaching a value of $-14 \%$ indicated the DIC resulted from carbonate dissolving by soil $\mathrm{CO}_{2}$, while the $\delta^{13} \mathrm{C}_{\mathrm{DIC}}$ in groundwater varying from $0 \%$ to $-14 \%$ o suggested the DIC resulted from carbonate dissolving by soil $\mathrm{CO}_{2}, \mathrm{HNO}_{3}$ and $\mathrm{H}_{2} \mathrm{SO}_{4}$ in the catchment. As shown in Tab. 2, the $\delta^{13} \mathrm{C}_{\mathrm{DIC}}$ of groundwater varied from $-12.4 \%$ to $-10.1 \%$ in different months, which deviate from the expected the $\delta^{13} \mathrm{C}_{\text {DIC }}(-14 \%$ ) of groundwater which DIC is derived from carbonate dissolving by natural soil $\mathrm{CO}_{2}$, suggesting that the DIC of groundwater not only resulted from carbonate dissolving by natural soil $\mathrm{CO}_{2}$, but also from carbonate dissolving by sulfur and nitric acids in the catchment in the QURS.

Thus, given the $\delta^{13} \mathrm{C}_{\text {soil CO2 }}(-23.3 \%), \delta^{13} \mathrm{C}_{\text {carbonate }}$ $(0.25 \%$ ) and fractionation of isotopic compositions $\left(+9 \%\right.$ ) in groundwater system, the theoretical $\delta^{13} \mathrm{C}_{\mathrm{DIC}}$ value of groundwater that DIC was derived from different sources (carbonate dissolution and soil $\mathrm{CO}_{2}$ ) can be calculated by the following equation:

$\delta^{13} C_{D I C}=\left[\sum_{0}^{i}(m C i)\left(\delta^{13} C i\right)\right] /\left[\sum_{0}^{i}(m C i)\right]$

where $\delta^{13} \mathrm{C}_{\mathrm{DIC}}$ is the theoretical $\delta^{13} \mathrm{C}_{\mathrm{DIC}}$ value of groundwater, $m C_{i}$ is the molality of added DIC from the $i$ th source (carbonate dissolution by carbonic acid and sulphuric/nitric acids, respectively), and the $\delta^{13} \mathrm{C}_{\mathrm{i}}$ is $\delta^{13} \mathrm{C}$ composition of added DIC from the $i$ th source $\left(\right.$ soil $\mathrm{CO}_{2}$ and carbonate).

The calculated results of the theoretical $\delta^{13} \mathrm{C}_{\mathrm{DIC}}$ values of groundwater are shown in Tab. 2. The measured $\delta^{13} \mathrm{C}_{\mathrm{DIC}}$ value of monthly groundwater sample is much closed to its corresponding calculated $\delta^{13} \mathrm{C}_{\mathrm{DIC}}$ value. Thus, the elevated $\delta^{13} \mathrm{C}_{\mathrm{DIC}}$ (varying from $-11.1 \%$ to $-10.3 \%$ with an average of $-10.6 \%$ ) of groundwater in the rainy season and fertilizing period suggested that carbonate dissolving was significantly influenced by nitric and sulphuric acids originated from the use of $\mathrm{N}$-fertilizers and atmospheric acid deposition in the catchment.

As indicated in Fig. 2, the $\delta^{13} \mathrm{C}_{\mathrm{DIC}}$ increased with DIC in groundwater collected from the rainy season and fertilizing period, indicating that the use of $\mathrm{N}$-fertilizers and atmospheric acid deposition could be responsible for the elevated DIC concentrations and $\delta^{13} \mathrm{C}_{\mathrm{DIC}}$ of groundwater in the catchment. Meanwhile, an intense positive relationship between the $\delta^{13} \mathrm{C}_{\mathrm{DIC}}$ and $\left(\mathrm{Ca}^{2+}+\mathrm{Mg}^{2+}\right) /$ $\mathrm{HCO}_{3}^{-}$was observed (Fig. 4). The $\delta^{13} \mathrm{C}_{\mathrm{DIC}}$ increased obviously with $\left(\mathrm{Ca}^{2+}+\mathrm{Mg}^{2+}\right) / \mathrm{HCO}_{3}^{-}$in groundwater collected from the rainy season and fertilizing period, indicating that the use of $\mathrm{N}$-fertilizers and atmospheric acid deposition could be responsible for the elevated the $\delta^{13} \mathrm{C}_{\mathrm{DIC}}$ and the molar ratio of $\left(\mathrm{Ca}^{2+}+\mathrm{Mg}^{2+}\right) / \mathrm{HCO}_{3}^{-}$of groundwater. Also, as indicated by Fig. 4 , the $\delta^{13} \mathrm{C}_{\mathrm{DIC}}$ varying from $-10 \%$ to $-12.5 \%$, with a variational molar ratio between $\left(\mathrm{Ca}^{2+}+\mathrm{Mg}^{2+}\right)$ and $\mathrm{HCO}_{3}^{-}$of 0.53 to 0.63 of groundwater in different months, indicated the carbonate was

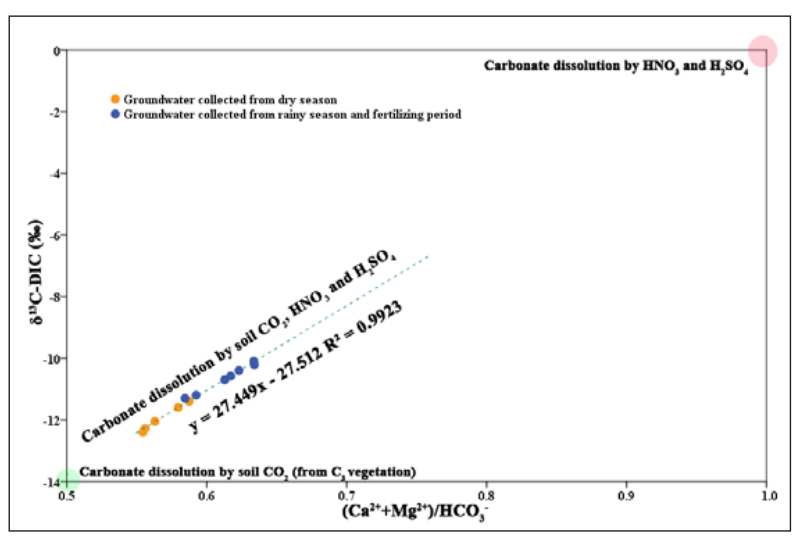

Fig. 4: Cross plot of (a) $\delta^{13} \mathrm{C}_{D I C}$ vs. $\left(\mathrm{Ca}^{2+}+\mathrm{Mg}^{2+}\right) / \mathrm{HCO}_{3}^{-}$of groundwater in different seasons.

dissolved by soil $\mathrm{CO}_{2}$ (from $\mathrm{C}_{3}$ vegetation), $\mathrm{HNO}_{3}$ and $\mathrm{H}_{2} \mathrm{SO}_{4}$ in the catchment. Thus, the evidences from both of the chemical data and $\delta^{13} \mathrm{C}_{\mathrm{DIC}}$ of groundwater in different months indicated that carbonate dissolution was controlled by natural carbonic acid, and nitric and sulphuric acids originated from the use of $\mathrm{N}$-fertilizers and atmospheric acid deposition in the QURS.

\section{CONCLUSIONS}

Although the results of this study are preliminary and the effects of the use of N-fertilizers and acid deposition on carbonate weathering have been quantified in a small karstic agricultural catchment of Southwest China.
The significant temporal variations for major element concentrations and $\delta^{13} \mathrm{C}_{\mathrm{DIC}}$ of groundwater in different months were observed in the QURS. The groundwater collected in rainy season and fertilizing period showed significant high concentrations of DIC, $\mathrm{Ca}^{2+}$, 
$\mathrm{Mg}^{2+}, \mathrm{NO}_{3}^{-}, \mathrm{SO}_{4}^{2-}$ and $\delta^{13} \mathrm{C}_{\mathrm{DIC}}$. These temporal variations could be attributed to carbonate dissolution by natural carbonic acid, and nitric and sulphuric acids introduced by the use of $\mathrm{N}$-fertilizers and atmospheric acid deposition in the QURS.

The contributions of carbonate dissolution by carbonic acid to total concentrations of $\left(\mathrm{Ca}^{2+}+\mathrm{Mg}^{2+}\right)$ and $\mathrm{HCO}_{3}^{-}$of groundwater in different months averaged $68.5 \%$ and $81 \%$, respectively. While the contributions of carbonate dissolution by nitric and sulphuric acids originated from the use of $\mathrm{N}$-fertilizers and atmospheric acid deposition to total concentrations of $\left(\mathrm{Ca}^{2+}+\mathrm{Mg}^{2+}\right)$ and $\mathrm{HCO}_{3}^{-}$of groundwater in different months averaged $11.1 \%$ and $6.7 \%$, and $20.4 \%$ and $12.3 \%$, respectively. Especially, the contributions of carbonate dissolution by carbonic acid to total concentrations of $\left(\mathrm{Ca}^{2+}+\mathrm{Mg}^{2+}\right)$ and $\mathrm{HCO}_{3}^{-}$of groundwater averaged only $63 \%$ and $77 \%$, while the contributions of carbonate dissolution by nitric and sulphuric acids to total concentrations of $\left(\mathrm{Ca}^{2+}+\mathrm{Mg}^{2+}\right)$ and $\mathrm{HCO}_{3}^{-}$of groundwater averaged $37 \%$ and $23 \%$ in rainy season and fertilizing period (from Apr. to Oct.).

The temporal variations of $\delta^{13} \mathrm{C}_{\mathrm{DIC}}$ in groundwater (varying from $-12.4 \%$ to $-10.1 \%$ ) in different months deviated from the expected the $\delta^{13} \mathrm{C}_{\mathrm{DIC}}(-14 \%)$ of groundwater which DIC is derived from carbonate dissolving by natural soil $\mathrm{CO}_{2}$, suggesting that the DIC of groundwater not only resulted from carbonate dissolving by natural soil $\mathrm{CO}_{2}$, but also from carbonate dissolving by sulfur and nitric acids in the QURS. Meanwhile, the $\delta^{13} \mathrm{C}_{\mathrm{DIC}}$ increased obviously with $\left(\mathrm{Ca}^{2+}+\mathrm{Mg}^{2+}\right) / \mathrm{HCO}_{3}^{-}$of groundwater in the rainy season and fertilizing period, indicating that the use of $\mathrm{N}$-fertilizers and atmospheric acid deposition should be responsible for the elevated the $\delta^{13} \mathrm{C}_{\mathrm{DIC}}$ and the molar ratio of $\left(\mathrm{Ca}^{2+}+\mathrm{Mg}^{2+}\right) / \mathrm{HCO}_{3}^{-}$of groundwater in the QURS.

Thus, the evidences from both of the hydrochemical data and $\delta^{13} \mathrm{C}_{\mathrm{DIC}}$ of groundwater in different months indicated that carbonate dissolution was not only controlled by natural carbonic acid, but also by sulphuric and nitric acids introduced by the use of N-fertilizers and atmospheric acid deposition in the QURS. More important is that not only the concentrations of nitrate and sulphate in karst groundwater have been elevated, but also the exports of inorganic carbon and $\left(\mathrm{Ca}^{2+}+\mathrm{Mg}^{2+}\right)$ have been enhanced due to carbonate weathering by nitric and sulphuric acids originated from the use of $\mathrm{N}$-fertilizers and atmospheric acid deposition in the catchment.

\section{ACKNOWLEDGMENTS}

This work is financially supported by National Natural Science Foundation of China (Grant Nos. 41472321 and 41172331), and IGCP598.

\section{REFERENCES}

Ali, H.N. \& E.A. Atekwana, 2011: The effect of sulfuric acid neutralization on carbonate and stable carbon isotope evolution of shallow groundwater-Chemical Geology, 284, 217-228. http://dx.doi. org/10.1016/j.chemgeo.2011.02.023

Atekwana, E.A. \& R.V. Krishnamurthy, 1998: Seasonal variations of dissolved inorganic carbon and $\delta^{13} \mathrm{C}$ of surface waters: application of a modified gas evolution technique.- Journal of Hydrology, 205, 265-278. http://dx.doi.org/10.1016/S0022-1694(98)00080-8
Barnes, R.T. \& P.A. Raymond, 2009: The contribution of agricultural and urban activities to inorganic carbon fluxes within temperate watersheds.- Chemical Geology, 266, 3-4, 327-336. http://dx.doi. org/10.1016/j.chemgeo.2009.06.018

Calmels, D., Gaillardet, J., Brenot, A. \& C. France-Lanord, 2007: Sustained sulfide oxidation by physical erosion processes in the Mackenzie River basin: Climatic perspectives.- Geology, 35, 11, 1003-1006. http://dx.doi.org/10.1130/G24132A.1

Deines, P., 2004: Carbon isotope effects in carbonate systems.- Geochimica et Cosmochimica Acta, 68, 2659-2679. http://dx.doi.org/10.1016/j. gca.2003.12.002 
Dentener, F., Drevet, J., Lamarque, J.F., Bey, I., Eickhout, B., Fiore, A.M., Hauglustaine, D., Horowitz, L.W., Krol, M., Kulshrestha, U.C., Lawrence, M., Galy-Lacaux, C., Rast, S., Shindell, D., Stevenson, D., Noije, T. van, Atherton, C., Bell, N., Bergman, D., Butler, T., Cofala, J., Collins, B., Doherty, R., Ellingsen, K., Galloway, J., Gauss, M., Montanaro, V., Müller, J.F., Pitari, G., Rodriguez, J., Sanderson, M., Solmon, F., Strahan, S., Schultz, M., Sudo, K., Szopa S. \& O. Wild, 2006: Nitrogen and sulfur deposition on regional and global scales: A multimodel evaluation.- Global Biogeochemical Cycles, 20, GB4003, 1-21. http://dx.doi.org/10.1029/2005GB002672

Gandois, L., Perrin, A.-S. \& A. Probst, 2011: Impact of nitrogenous fertiliser-induced proton release on cultivated soils with contrasting carbonate contents: a column experiment.- Geochimica et Cosmochimica Acta, 75, 1185-1198. http://dx.doi.org/10.1016/j. gca.2010.11.025

He, Q., Yang P., Yuan, W., Jiang, Y., Pu, J., Yuan, D. \& Y. Kuang, 2010: The use of nitrate, bacteria and fluorescent tracers to characterize groundwater recharge and contamination in a karst catchment, Chongqing, China.- Hydrogeology Journal, 18, 1281-1289. http://dx.doi.org/ 10.1007/s10040-010-0594-0

Jiang, Y., 2012: Sources of sulfur in the Nandong underground river system, southwest China: A chemical and isotopic reconnaissance.- Applied Geochemistry, 27, 8, 1463-1470. http://dx.doi.org/10.1016/j. apgeochem.2012.05.001

Jiang, Y., 2013: The contribution of human activities to dissolved inorganic carbon fluxes in a karst underground river system: evidence from major elements and $\delta^{13} \mathrm{C}_{\mathrm{DIC}}$ in Nandong, Southwest China.- Journal of Contaminant Hydrology, 152, 1-11. http:// dx.doi.org/10.1016/j.jconhyd.2013.05.010.

Jiang, Y., Wu, Y., Groves, C., Yuan, D. \& P. Kambesis, 2009a: Natural and anthropogenic factors affecting the groundwater quality in the Nandong karst underground river system in Yunan, China.- Journal of Contaminant Hydrology, 109, 49-61. http:// dx.doi.org/10.1016/j.jconhyd.2009.08.001

Jiang, Y., Wu, Y. \& D. Yuan, 2009b: Human impacts on karst groundwater contamination deduced by coupled nitrogen with strontium isotopes in the Nandong underground river system in Yunan, China.- Environmental Science \& Technology, 43, 7676-7683. http://dx.doi.org/10.1021/es901502t

Jiang, Y., Yuan, D., Zhang, C., Zhang, G. \& R. He, 2008: Impact of land use change on groundwater quality in a typical karst watershed of southwest China.- Hydrogeology Journal, 16, 4, 727-735. http:// dx.doi.org/10.1007/s10040-007-0259-9
Li, S., Calmel, D., Han, G., Gaillardet, J. \& C. Liu, 2008: Sulfuric acid as an agent of carbonate weathering constrained by $\delta^{13} \mathrm{C}_{\mathrm{DIC}}$ : Examples from Southwest China.- Earth and Planetary Science Letters, 270, 189-199. http://dx.doi.org/10.1016/j. epsl.2008.02.039

Li, S., Liu, C., Li, J., Lang, Y., Ding, H. \& L. Li, 2010: Geochemistry of dissolved inorganic carbon and carbonate weathering in a small typical karstic catchment of Southwest China: Isotopic and chemical constraints.- Chemical Geology, 277, 301-309. http://dx.doi.org/10.1016/j.chemgeo.2010.08.013

Liu, C., Li, S., Lang, Y. \& H. Xiao, 2006: Using $\delta^{15} \mathrm{~N}-$ and $\delta^{18} \mathrm{O}$-values to identify nitrate sources in karst ground water, Guiyang, southwest China.- Environmental Science \& Technology, 40, 22, 6928-6933. http://dx.doi.org/10.1021/es0610129

Liu, C., Lang, Y., Satake, H., Wu, J. \& S. Li, 2008: Identification of anthropogenic and natural inputs of sulfate and chloride into the karstic ground water of Guiyang, SW China: Combined $\delta^{37} \mathrm{Cl}$ and $\delta^{34} S$ approach.- Environmental Science \& Technology, 42, 15, 5421-5427. http://dx.doi.org/10.1021/ es $800380 \mathrm{w}$

Paulot, F., Jacob, D.J. \& D.K. Henze, 2013: Sources and processes contributing to nitrogen deposition: an adjoint model analysis applied to biodiversity hotspots worldwide.- Environmental Science \& Technology, 47, 7, 3226-3233. http://dx.doi. org/10.1021/es3027727

Perrin, A.-S., Probst, A. \& J.-L. Probst, 2008: Impact of nitrogenous fertilizers on carbonate dissolution in small agricultural catchments: implications for weathering $\mathrm{CO}_{2}$ uptake at regional and global scales.- Geochimica et Cosmochimica Acta, 72, 3105-3123. http://dx.doi.org/10.1016/j. gca.2008.04.011

Pu, J., Yuan, D., He, Q., Wang, Z., Hu, Z. \& P. Gou, 2011: High-resolution monitoring of nitrate variations in a typical subterranean karst stream, Chongqing, China.- Environmental Earth Science, 64, 7, 1985-1993. http://dx.doi.org/10.1007/s12665-0111019-7

Semhi, K., Suchet, P. A., Clauer, N. \& J.-L. Probst, 2000: Impact of nitrogen fertilizers on the natural weathering-erosion processes and fluvial transport in the Garonne basin.- Applied Geochemistry, 15, 6, 865-874. http://dx.doi.org/10.1016/S0883-2927(99)00076-1

Tang, J., Xu, X., Ba J. \& S. Wang, 2010: Trends of the precipitation acidity over China during 1992-2006.Chinese Science Bulletin, 55, 17, 1800-1807. http:// dx.doi.org/s11434-009-3618-1 
Yue F.-J., Li S.-L., Liu C.-Q., Lang Y.-C. \& H. Ding, 2015: Sources and transport of nitrate constrained by the isotopic technique in a karst catchment: an example from Southwest China.- Hydrological Processes, 29, 8, 1883-1893. http://dx.doi.org10.1002/hyp.10302/
Zhang, J., Quay, P.D. \& D.O. Wilbur, 1995: Carbon isotope fractionation during gas-water exchange and dissolution of $\mathrm{CO}_{2}$.- Geochimica et Cosmochimica Acta, 59, 107-114. http://dx.doi.org/10.1016/00167037(95)91550-D 